\title{
MANAJEMEN DAN PENDISTRIBUSIAN ZAKAT DALAM UPAYA PENINGKATAN KESEJAHTERAAN SOSIAL MASYARAKAT
}

\author{
Nur Afni \\ Dosen Universitas Al-Khairat Palu \\ nur.afni.tadjuddin87@gmail.com
}

\begin{abstract}
Abstrack
The management of zakat in relation to economic empowerment means that zakat as an asset of an Islamic economic institution, zakat is a source of strategic potential funds for efforts to build the welfare of the people. Because of that, the Koran gives a sign that the zakat collected is managed appropriately and effectively. The purpose of this research is to describe how the management and distribution of zakat to improve the social welfare of society. The type of research used in this research is library research or library research conducted by collecting data or scientific papers aimed at the research object. The results of the discussion in the article are; 1) in the process of managing zakat, it can be realized seriously, of course, this needs to be supported by good management, as was done in the early days of Islam. Managing zakat effectively and efficiently needs to be managed properly. Therefore, the management of zakat provides the application of modern management functions. 2) Zakat must be distributed to mustahik under Islamic law. 3) the distribution of zakat is carried out based on a priority scale, with due observance of the principles of equity, justice, and territoriality, and 4) Zakat is distributed through two distribution models directly or consumptive zakat, and indirect distribution, namely productive zakat.
\end{abstract}

Keywords: management zakat, distribution, social welfare

\section{Abstrak}

Pengelolaan zakat dalam keterkaitannya dengan pemberdayaan ekonomi memiliki makna bahwa zakat sebagai aset satu lembaga ekonomi Islam, zakat merupakan sumber dana potensial strategis bagi upaya membangun kesejahteraan umat. Karena itu al-Qur"an memberi rambu agar zakat yang dihimpun dikelola dengan tepat dan efektif. Tujuan penelitian ini yaitu menggambarkan bagaimana manajamen dan pendistribusian zakat dalam upaya peningkatan kesejahteraan sosial masyarakat. jenis penelitian yang digunakan dalam penelitian ini adalah penelitian kepustakaan atau library research dilakukan melalui mengumpulkan data atau karya tulis ilmiah yang bertujuan dengan obyek penelitian. Adapun hasil pembahasan pada artikel adalah; 1) dalam proses pengelolaan zakat dapat direlisasikan dengan sungguh-sungguh, tentu saja ini perlu didukung dengan menejemen yang baik, seperti pernah dilakukan pada masa awal-awal Islam. Pengelolaan zakat secara efektif dan efisien, perlu di-manage dengan baik. Karena itu, dalam pengelolaan zakat memberikan penerapan fungsi menejemen modern. 2) Zakat wajib didistribusikan kepada mustahik sesuai dengan syariat Islam. 3) pendistribusian zakat dilakukan berdasarkan skala prioritas, dengan memeperhatikan prinsip pemerataan, keadilan, dan kewilayahan, dan 4) Zakat didistribusikan lewat 
dua model pendistribusian secara langsung atau zakat konsumtif, dan pendistribusian secara tidak langsung, yaitu zakat produktif.

Kata kunci: manajemen, pendistribusian zakat, kesejahteraan sosial

\section{Pendahuluan}

Zakat sebagai rukun Islam yang ke 3 (tiga) dan merupakan kewajiban otrang Islam yang mampu untuk membayarnya dan diperuntukkan bagi mereka yang berhak menerimanya. Dengan pengelolaan yang baik, zakat merupakan dana potensial yang dimanfaatkan untuk memajukan kesejahteraan umum bagi seluruh masyarakat. ${ }^{1} \mathrm{Di}$ Indonesia, ada 2 (dua) kelembagaan pengelolaan zakat yang diakui pemerintah, yaitu Badan Amil Zakat (BAZ) dan lembaga Amil Zakat (LAZ). Keduanya telah mendapatkan payung perlindungan dari pemerintah, ${ }^{2}$ wujud perlindungan pemerintah terhadap kelembagaan pengelola zakat tersebut adalah undang-undang RI nomor 23 Tahun 2011 tentang pengelolaan zakat. ${ }^{3}$

Zakat merupakan salah satu rukun yang bercorak sosial- ekonomi dari lima rukun Islam. Dengan zakat, di samping ikrar tauhid dan shalat, seseorang barulah sah masuk ke dalam barisan umat Islam dan diakui keIslamannya. Di dalam zakat terdapat dua dimensi peribadatan, yaitu dimensi vertikal yang hubungannya antara kaum muslim dengan Allah Swt, dan dimensi horizontal dimana seorang muslim itu akan selalu berhubungan dengan muslim yang lain.

Agar zakat mampu memberi pengaruh signifikan terhadap perekonomian masyarakat, maka potensi zakat harus dioptimalkan. Pendistribusian zakat sebaiknya diprioritaskan untuk membangun usaha produktif bagi penerima zakat yang mampu mendatangkan pendapatan bagi mereka dan bahkan menyerap tenaga kerja. Lebih lanjut Didin Hafidhuddin mengatakan bahwa zakat yang dikelola dengan baik akan mampu membuka lapangan kerja dan usaha yang luas sekaligus penguasaan aset-aset umat Islam. ${ }^{4}$

Zakat sebagai institusi ekonomi umat dapat dikelola dan didistribusikan secara lebih baik. Tidak hanya diberikan dalam bentuk konsumtif, tetapi dapat dikembangkan dalam bentuk pemberian investasi (produktif), sehingga dengan demikian misi utama zakat untuk mewujudkan pemerataan zakat. Upaya pendayagunaan harta zakat pada usaha-usaha yang bersifat produktif itu dimaksudkan agar mustabik tidak dididik menjadi masyarakat yang bersifat konsumtif. ${ }^{5}$ Sedangkan dalam dimensi ekonomi, zakat mencegah penumpukan harta kekayaan pada

${ }^{1}$ Elsi Kartika Sari, Pengantar Hukum Zakat dan Wakaf (Jakarta: Grasindo, 2006), h. 1.

${ }^{2}$ Yadi Janwari Djazuli, Lembaga-lembaga Perekonomian Umat (Jakarta: Raja Grafindo Persada, 2002), h. $39-40$.

${ }^{3}$ Saefudin Zuhri, Zakat di Era Reformasi (Semarang: Aneka Ilmu, 2004), h. 8

${ }^{4}$ Didin Hafifdhuddin, Zakat dalam Perekonomian Modern (Jakarta: Gema Insani Press 2002), h. 15.

${ }_{5}^{5}$ jazuli Yadi Janwari, Lembaga-lembaga Perekonomian Ummat (Jakarta: Raja Grafindo Persada, 2002), h. 49. 
segelintir orang tertentu yang pada akhirnya akan berdampak pada ekonomi secara keseluruhan. $^{6}$

Dana zakat yang disalurkan ke masyarakat atau tepatnya kepada mustabik lebih banyak digunakan untuk kepentingan konsumtif, artinya zakat yang bersumber dari para muzakki yang menunaikan zakatnya digunakan hanya untuk memenuhi kebutuhan sehari-hari, dimana kebutuhan itu akan habis setelah pemakaian atau pemanfaatannya, sehingga tidak bisa digunakan kembali untuk waktu berikutnya atau tidak produktif. Hal tersebut tidak menjadikan para mustabik untuk bisa keluar dari permasalahan ekonominya, karena hanya diberikan berupa dana yang tentunya habis setelah digunakan, tanpa dikelola sebagai modal usaha yang diharapkan mampu mengembangkan kegiatan ekonomi dan meningkatkan taraf kehidupan keluarga, hal inilah yang disebut kegiatan produktif. ${ }^{7}$

Apabila dana zakat yang diberikan kepada mustabik, maka dana tersebut memiliki peran dalam peningkatan ekonomi mereka apabila dikonsumsikan pada kegiatan produktif. Pendayagunaan zakat produktif sebenarnya mempunyai konsep perencanaan dan pelaksanaan yang cermat, karena mengkaji penyebab kemiskinan, ketiadaan modal kerja, dan sempitnya lapangan pekerjaan. Dengan temuan permasalahan itu, dana zakat dapat direncanakan untuk menanggulangi permasalahan tersebut dengan melaksanakan kegiatan-kegiatan produktif, artinya dana zakat yang digulirkan kepada mustahik, dapat digulirkan kepada berbagai usaha sehingga didapat penghasilan untuk kemudian dikembangkan lagi. Bermula dari pemberian zakat produktif berupa modal kerja, maka usaha yang dijalankan mustabik akan mendapatkan, keuntungan, dalam mengembangkan usahanya, serta digunakan untuk menabung guna kebutuhan di masa mendatang. Hal ini menjadikan bahwa zakat produktif sangat berperan dalam produktifitas mustabik. ${ }^{8}$

Berdasarkan latar belakang di atas, yang menjadi pokok permasalahan dalam pembahasan penelitian ini adalah Bagaimana manajemen dan pendistribusian zakat dalam upaya peningkatan kesejahteraan sosial masyarakat?

\footnotetext{
${ }^{6}$ Ruslan Abdul Ghofur Noor, Konsep Distribusi Ekonomi Islam dan Format Keadila Ekonomi di Indonesia (Yogyakarta: Pustaka Pelajar, 2013), h. 100

${ }^{7}$ Asnaini, Zakat Produktif dalam Perspektif Islam (Yogyakarta: Pustaka Pelajar, 2008), h. 134.

8Umrotun Khasanah, Manajemen Zakat Modern (Malang: UIN-Maliki Press, 2010), h. 80.
} 


\section{Metode}

Adapun jenis penelitian yang digunakan dalam penelitian ini adalah penelitian kepustakaan atau library research, yakni penelitian yang dilakukan melalui mengumpulkan data ataukarya tulis ilmiah yang bertujuan dengan obyek penelitian atau pengumpulan data yang bersifat kepustakaan, atau telaah yang dilaksanakan untuk memecahkan suatu masalah yang pada dasarnya tertumpu pada penelaahan kritis dan mendalam terhadap bahan-bahan pustaka yang relevan. Sebelum melakukan telaah bahan pustaka, peneliti harus mengetahui terlebih dahulu secara pasti tentang dari sumber mana informasi ilmiah ituakan diperoleh. Adapun beberapa sumber yang digunakan antara lain; buku-buku teks, jurnal ilmiah, refrensi statistik, hasil-hasil penelitian dalam bentukskripsi, tesis, desertasi,dan internet, serta sumbersumber lainnya yang relevan. ${ }^{9}$

\section{Pembahasan}

\section{Manajemen Zakat dalam Upaya Peningkatan Kesejahteraan Sosial Masyarakat.}

\section{Manajemen Zakat}

Zakat merupakan ibadah yang bersifat mäliyah ijtimä'iyyah yang harus dikelola dengan cara profesional. Hal ini dilakukan karena pengelolaan yang profesional akan meningkatkan peluang membaiknya pelayanan bagi masyarakat dalam menunaikan zakat sesuai dengan tuntutan agama. Terlebih fungsi dan peran zakat sendiri yakni mewujudkan kesejahteraan masyarakat dan keadilan sosial. Untuk melihat gambaran secara jelas dalam macam-macam manajemen zakat itu sendiri, akan diuraikan macam-macam manajemen zakat mulai dari manajemen zakat klasik hingga manajemen zakat modern. Diantaranya:

\section{a. Manajemen Zakat Klasik}

Terkait dengan zakat, pada masa klasik manajemen tampaknya belum banyak diperhatikan orang. Zakat masih dianggap persoalan ringan yang tidak perlu dikelola secara profesional. Apalagi ketika disebut zakat, orang segera mempersepsikan pada zakat fitrah yang dikeluarkan di akhir bulan Ramadhan. Dengan demikian manajemen tidak diperlukan dalam hal pengelolaan zakat. ${ }^{10}$ Sudirman dalam Zakat dalam Pusaran Arus Modernitas menjelaskan bahwa ada beberapa faktor yang menyebabkan pengelolaan zakat pada masa klasik tidak maksimal di antaranya:

1). Sikap Menyepelekan

Pengelolaan zakat dianggap sepele pada masa klasik, karena zakat sifatnya hanya bantuan dan pengelolaan bantuan itu merupakan pekerjaan sosial semata.

\footnotetext{
9 Anwar Sanusi, Metodologi Penelitian Bisnis (Jakarta: Salemba Empat, 2016), h. 32

${ }^{10}$ Sudirman, Zakat dalam Pusaran Arus Modernitas (Malang: UIN Malang Pres, 2007), h. 72.
} 
Pekerjaansosial bisa dilakukan dengan santai tanpa ada beban. Pandangan semacam ini semakin memperkeruh situasi, sebab kebanyakan pengelola zakat menganggap tanpa zakat mereka sudah dapat menikmati hidup layak sesuai dengan standar hidup mereka. Mereka belum pernah merasakan para mustabik menunggu uluran tangan muzakeki. Misalnya orang yang tidak mampu, seperti fakir, miskin dan lain sebagainya, harus mati-matian bertahan hidup dan menunggu kapan nasib akan berubah. Sedangkan bagi muzakki, jika dia ingin menunaikan maka ia akan menunaikan zakat. Sikap seperti inilah yang kemudian dinilai kurang manusiawi dan belum bisa mendudukan pada tempat yang benar. Penyepelean kepada zakat akan berakibat kepada tidak akan terpenuhinya kebutuhan orang- orang yang secara ekonominya kurang beruntung. ${ }^{11}$

2). Tanpa Manajemen

Pengelolaan zakat sering kali tanpa bentuk manajemen yang jelas. Pembagian tugas dan struktur organisasi hanya formalitas tanpa adanya alasan yang jelas. Struktur hanya disesuaikan dengan keinginan sang pengelola atau si pendiri, bukan berdasarkan kebutuhan riil organisasi. Pembagian tugas juga belum sepenuhnya nyata dan dipahami oleh anggota organisasi. Efeknya organisasi bisa berjalan namun lambat, biasanya organisasi seperti ini hanya awalnya saja yang berjalan dengan lancar, namun lambat laun akan menimbulkan kejenuhan, kecemburuan kerja dan pada akhirnya yang bekerja hanya beberapa orang saja. Sedihnya lagi, kondisi ini tidak banyak yang memahami karena sikap egois masing-masing. Akhirnya organisasi tanpa manajemen yang jelas akan mandeg atau berjalan di tempat. ${ }^{12}$

3). Minus Monitoring dan Evaluasi

Salah satu dampak dari tidak adanya manajemen adalah tidak adanya sistem monitoring dan evaluasi. Jalannya organisasi masih sangat bergantung pada pimpinan yang menjadi kata kunci dalam kebanyakan organisasi. Model organisasi yang terlalu banyak mengandalkan kepada eksistensi pimpinan menyebabkan lemahnya sistem pengawasan dan evaluasi Dengan tidak adanya kedua elemen tersebut, dapat dibayangkan bahwa lembaga itu akan sulit berbenah bahkan berkembang untuk bersaing dengan lembaga lain. Apalagi ketika ada persoalan yang muncul, pimpinan yang terbatas kemampuannya berperang seolah-olah mengatasi masalah. ${ }^{13}$

Para bawahan pun seakan tidak punya kemampuan untuk menyampaikan pendapatnya. Semua nampaknya bisa menerima keputusan apa saja yang keluar dari pimpinan. Proses pengambilan dan penyelesaian masalah seperti ini adalah model yang keliru. Tidak ada proses pendewasaan yang sehat di lembaga tersebut. Repotnya lagi ketika munculnya suatu masalah, dan ketika itu pimpinan

${ }^{11}$ Ibid, h. 73.

${ }^{12}$ Ibid.,

13Ibid., 
tidak ada di tempat, maka bawahannya akan merasa kebingungan menentukan sikap, dan bisa berakibat munculnya konflik berkepanjangan.

Oleh karena itulah pentingnya pengawasan dan evaluasi yang dilakukan semua organisasi, yang bisa memunculkan manajemen yang sehat. Dengan tidak adanya kedua elemen tersebut, dapat dibayangkan bahwa lembaga itu akan sulit berbenah bahkan berkembang untuk bersaing dengan lembaga lain. Apalagi ketika ada persoalan yang muncul, pimpinan yang terbatas kemampuannya berperang seolah-olah mengatasi masalah.

4). Tidak Biasa Disiplin

Tidak biasa disiplin merupakan salah satu budaya di Indonesia yang kurang baik, sehingga molor merupakan suatu keharusan. Kenyataan seperti ini tidak hanya ditemui di kalangan bawah saja, akan tetapi sudah merambat di kalangan para pejabat kita, baik di tingkat propinsi maupun pusat. Tidak hanya dimiliki para karyawan, namun para pelajar dan akademisi juga tidak terlepas dari kebiasaan kurang baik ini. Memang sedikit aneh, ketika kita menyadari bahwa negara kita negara Muslim terbesar di dunia, akan tetapi tingkat kedisiplinannya tergolong rendah. Padahal setiap hari kita telah dilatih oleh ajaran agama kita untuk melakukan shalat lima waktu dengan aturan waktu yang telah ditentukan. ${ }^{14}$

Dari poin-poin di atas setidaknya dapat disimpulkan, bahwa lembaga-lembaga sosial di Indonesia, termasuk salah satunya adalah institusi pengelola zakat menghadapi tiga masalah besar yang harus segera diselesaikan, yaitu kualitas sumber daya manusia yang kurang maksimal, manajemen yang masih minimal dan lemahnya etos kerja. Masalah-masalah seperti ini harusnya dapat diselesaikan secara bertahap dengan merubah cara pandang pengelola lembaga sekaligus masyarakatnya.

\section{b. Manajemen Zakat Modern}

Dengan melihat proses-proses dan pengertian manajemen yang telah dipaparkan sebelumnya, maka manajemen zakat meliputi beberapa kegiatan, diantaranya yaitu perencanaan, pengorganisasian, pelaksanaan dan pengawasan terhadap pengumpulan dan pendistribusian zakat.

Istilah pengelolaan berasal dari kata mengelola yang berati mengendalikan atau menyelenggarakan. Sedangkan pengelolaan berati proses melalukam kegiatan tertentu dengan menggerakkan tenaga orang lain, atau dapat juga diartikan proses pemberian pengawasan pada semua hal yang terlibat dalam pelaksanaan kebijaksanaan dan pencapaian tujuan. Pemahaman tersebut bahwa pengelolaan menyangkut proses suatu aktifitas. Dalam kaitannya dengan zakat, proses tersebut meliputi sosialisasi zakat, pengumpulan zakat, pendistribusian dan pendayagunaan dan pengawasan. Dengan demikian yang dimaksud pengelolaan zakat adalah proses 
dan pengorganisasian sosialisasi, pengumpulan, pendistribusian, dan pengawasan dalam pelaksanaan zakat. ${ }^{15}$

Pengelolaan zakat dalam keterkaitannya dengan pemberdayaan ekonomi memiliki makna bahwa zakat sebagai aset satu lembaga ekonomi Islam, zakat merupakan sumber dana potensial strategis bagi upaya membangun kesejahteraan umat. Karena itu al- Qur"an memberi rambu agar zakat yang dihimpun dikelola dengan tepat dan efektif. Jadi pengelolaan zakat bukan hanya berbicara memberdayakan dana zakat para muzakki untuk tujuan pemberdayaan mustahik. Namun, pengelolaan zakat sebagai salah satu pilar ajaran Islam, pengumpulan, penggunaan, dan pemberdayaan ekonomi mustahik, dan pengawasan zakat. Pengelolaan zakat untuk pemberdayaan ekonomi menempatkan perencanaan, pengorganisasian, penggerakan, dan pengawasan, agar zakat dapat disyari"eatkan untuk merubah mustahik menjadi muzakki. ${ }^{16}$

Dalam proses pengelolaan zakat dapat direlisasikan dengan sungguhsungguh, tentu saja ini perlu didukung dengan menejemen yang baik, seperti pernah dilakukan pada masa awal-awal Islam. Pengelolaan zakat secara efektif dan efisien, perlu di-manage dengan baik. Karena itu, dalam pengelolaan zakat memberikan penerapan fungsi menejemen modern. Dalam hal ini, mengambil model menejemen sederhana yang dipelopori oleh James Stoner. Model menejemen tersebut meliputi Perencanaan, pengorganisasian, pengarahan, dan pengontrolan. Keempat aktivitas itu, perlu diterapkan dalam setiap tahapan aktivitas pengelolaan zakat. $^{17}$

1). Perencanaan Zakat

Sudah sejak lama konsep zakat diyakini mampu memberantas kemiskinan, dalam rumusan fiqih zakat kerap kali disebut sebagai pengabdian kepada Allah dalam bentuk pembelajaran, dalam teologi kontemporer disebut sebagai ibadah hubungan sesama manusia dengan prinsip mentransfer harta dari sikaya untuk yang miskin.

Melihat arti penting zakat baik bagi diri maupun untuk kemaslahatan masyarakat, semestinya bersegera untuk membayar zakat, tetapi kenyataannya lain, muzaki seolah-olah tidak tau dan tidak peduli tentang kewajiban berzakat dan berpangku tangan melihat kesenjangan sosial yang ada. Dengan demikian memaksa pihak pengawas (Amil) bekerja keras dalam menjalankan tugasnya untuk mengumpulkan zakat. Oleh karena itu pihak amil zakat harus mampu membuat pendekatan yang dapat memaksimalkan pendapatan dan pendekatan tersebut harus berorientasi pada kemaslahatan masyarakat. ${ }^{18}$

${ }^{15}$ Muhammad Hasan, Manajemen Zakat (Yogyakarta: Idea Press, 2011), h. 17

${ }^{16}$ Ahmad Rofik, Fiqh Kontekstual (Semarang: Offset, 2004), h. 259-260.

${ }^{17}$ Hasan, Menejemen, h. 21.

${ }^{18}$ M. Darmawan Raharjo, Islam dan Transformasi Sosial Ekonomi (Jakarta: LSI, 1999), 325. 


\section{2) Pengorganisasian}

Pengorganisasian adalah pengelompokan dan pengaturan sumberdaya manusia untuk dapat digerakan sebagai satu kesatuan sesuai dengan rencana yang telah dirumuskan, menuju mengadakan hubungan yang tepat antara seluruh tenaga kerja dengan maksud agar mereka bekerja secara efisien dalam mencapai tujuan yang sudah ditemukan sebelumnya. ${ }^{19}$ Pengorganisasian berati mengkoordinir pemanfaatan sumber daya manusia dan sumber daya materi yang dimiliki oleh lembaga Amil Zakat yang bersangkutan. ${ }^{20}$ Efektifitas sebuah amil zakat sangat ditentukan oleh pengorganisasian sumber daya yang dimiliki untuk mencapai tujuannya. Dengan demikian, semakin terkoordiner sumber daya manusia dan sumber daya materi sebuah amil akan semakin efektifitas amil tersebut.

3) Penggerakan

Penggerakan adalah suatu fungsi bimbingan agar orang kelompok itu suka dan mau bekerja. Penekanan yang terpenting dalam penggerakan adalah tindakan membimbing, mengarahkan, dan menggerakan, agar bekerja dengan baik, tenag, dan tekun, sehingga dipahami fungsi dan deferensiasi tugas masing-masingh. Hal ini diperlukan karena dalam suatu hubungan kerja, diperlulan suatu kondisi yang normal, baik, dan kekeluargaan. ${ }^{21}$ Untuk mewujudkan hal ini, tidak terepas dari peran piawai seseorang pemimpin harus mampu menuntun dan mengawasi bawahan agar yang sedang dikerjakan sesuai dengan yang direncanakan.

Berkaitan dengan pengelolaan zakat, penggerakan memiliki peran strategis dalam memberdayakan kemampuan sumber daya amil zakat. Dalam konteks ini penggerakan sekaligus memiliki fungsi sebagai motivasi, sehingga sumber daya amil zakat memiliki disiplin kerja tinggi.

Selain pergerakan perlu ditambah motivasi agar kegiatan manajemen zakat dapat terlaksana dengan maksimal karena motivasi motivasi mempunyai peran yang sangat penting dalam kegiatan. Agar kegiatan tersebut memberikan hasil yang efektif, maka perlu adanya motivasi yang kuat dan untuk itu perlu adanya usahausaha untuk membangkitkan motivasi. ${ }^{22}$

4) Pengawasan dan Evaluasi

Telah dijelaskan diatas bahwa pengertian zakat itu dimaksudkan untuk membangun manusia, yang dulunya mustahik menjadi muzakki dengan proses perencanaan dan pengelolaan yang tepat, namun demekian pembangunan manusia ini tidak semudah membalikan telapak tangan. Hanya dengan menyalurkan zakat kepada mustahik itu tidak akan menumbuhkan hasil seperti yang diharapkan tanpa adanya pengawasan pembangunan manusia ini tidak semudah membalikan telapak tangan dan evaluasi, oleh karena itu pengawas juga menjadi salah satu faktor yang

${ }^{19}$ Ibid, h. 327.

${ }^{20}$ Ibid.,

${ }^{21}$ Ibid.,

${ }^{22}$ Hairuddin Cikka, Strategi Komunikasi Guru Memotivasi Peserta Didik Dalam Meningkatkan Prestasi Belajar, Al-mishbah, Vol.15 No. 2 Juli - Desember 2019, h. 373. 
penting dalam proses pembayaran masyarakat. Pengawasan ini sifatnya dua arah, pertama, pengawasan bagi pihak amil, agar jangan sampai menyalagunakan dana zakat yang terkumpul. Kedua, pengawasan bagi mustahik, pengawasan ini meliputi beberapa hal antara lain: pengawasan dana zakat, kemampuan mustahik dalam menggunakan dana zakat antara bentuk pemberian dengan permasalahan yang dihadapi. Dengan adanya pengawasan ini diharapkan dana yang tersalurkan kepada pihak mustahik benar-benar dimanfaatkan sesuai dengan kebutuhannya dan akhirnya dapat meningkatkan kesejahteraan masyarakat. ${ }^{23}$

Sampai kapankah penyaluran dana harus dilakukan pemberdayaan tidak bersifat selamanya, melainkan sampai target masyarakat mampu untuk mandiri. Mesti sudah mandiri harus tetap dipantau agar kondisi dan kemampuan terus meningkat dengan cara mengevaluasi sejauh mana kemampuan mustahik dalam mengembangkan pemberdayaan dengan evaluasi bisa diketahui apakah mustahik sudah mandiri ataukah masih butuh binaan. ${ }^{24}$

Ditegaskan bahwa dengan adanya manajemen pengalokasian zakat agar lebih efektif dalam mengalokasikan dana zakat untuk para mustahik, dimana dapat diketahui bahwa dengan adanya menegement zakat dapat dikelola dengan baik dan bisa diketahui masalah-masalah dari pengelola maupun mustahik. Dan mampu mengetahui apakah pengelokasian tersebut sudah tepat atau masih perlu adanya pembinaan.

\section{Pola Distribusi Zakat dalam Peningkatan Kesejahteraan Sosial Masyarakat.}

Zakat yang di kumpulkan oleh lembaga pengelola zakat, harus segera disalurkan kapada para mustahik sesuai dengan skala prioritas yang telah disusun dalam program kerja. Zakat tersebut harus disalurkan kepada para mustahik sebagaimana tergambar dalam surah at-Taubah : 60, yang uraiannya antara lain sebagai berikut : (Pertama) : fakir dan miskin. Meskipun kedua kelompok ini memiliki perbedaan yang cukup signifikan, akan tetapi dalam teknis oprasional sering dipersamakan, yaitu mereka yang tidak memiliki penghasilan sama sekali, atau memilikinya akan tetapi sangat tidak mencukupi kebutuhan pokok dirinya dan keluarga yang menjadi tanggungannya. Zakat yang disalurkan pada kelompok ini dapat bersifat konsumtif, yaitu untuk memenuhi keperluan konsumsi sehari-harinya dan dapat pula bersifat produktif, yaitu untuk memenambah modal usahanya. Zakat yang bersifat konsumtif dinyatakan antara lain dalam Firman Allah Swt sebagai berikut yang artinya:

(Berinfaqlah) kepada orang-orang fakir yang terikat (oleh jihad) di jalan Allah; mereka tidak dapat (berusaha) di bumi; orang yang tidak tahu menyangka mereka orang Kaya karena memelihara diri dari minta-minta. kamu kenal

${ }^{23}$ Mubyarto, Membangun Sistem Ekonomi ( Yogyakarta: BPFE, 2000), h. 263.

${ }^{24}$ Ibid., 
mereka dengan melihat sifat-sifatnya, mereka tidak meminta kepada orang secara mendesak. dan apa saja harta yang baik yang kamu nafkahkan (di jalan Allah), Maka Sesungguhnya Allah Maha Mengatahui.(QS. Al-Baqarah [2]: 273). ${ }^{25}$

Infak diberikan kepada orang-orang yang fakir karena berjuang di jalan Allah sehingga tidak sempat mencari nafkah. Atau karena mereka terluka di medan perang yang membuat tidak bisa bekerja. Orang-orang yang tidak tahu, menganggap mereka kaya lantaran mereka menghindarkan diri dari meminta- minta. Padahal, jika kamu perhatikan, niscaya akan kamu ketahui keadaan sebenarnya melalui tanda- tandanya. Segala kebaikan yang kalian lakukan pasti Allah ketahui. Dan Dia akan membalasnya dengan yang setimpal. ${ }^{26}$

Dalam kaitan dengan pemberian zakat yang besifat produktif, terdapat pendapat yang menarik sebagaimana dikemukakan oleh Yusuf al-Qardhawi dalam Fiqih Zakat bahwa (Pertama), pemerintah Islam diperbolehkan membangun pabrikpabrik atau perusahaan-perusahaan dari uang zakat untuk kemudian kepemilikan dan keuntungannya bagi kepentingan fakir miskin, sehingga akan terpenuhi kebutuhan hidup mereka sepanjang masa. Pengganti pemerintah, untuk saat ini dapat diperankan oleh badan Amil zakat atau Lembaga Amil Zakat yang bersifat produktif harus pula melakukan pembinaan/ pendampingan kepada para mustahik agar kegiatan usahanya berjalan dengan baik, dan agar para mustahik semakin meningkatkan kualita keimanan dan keIslamanya. ${ }^{27}$

(Kedua): Kelompok Amil (Petugas Zakat). Kelompok ini berhak mendapatkan bagian dari Zakat, maksimal satu perdelapan atau 12.5 persen, dengan catatan bahwa petugas Zakat ini memang melakukan tugas-tugas keamilan dengan sebaik-baiknya dan waktunya sebagian besar atau seluruhnya untuk tugas tersebut. Jika hanya di akhir bulan Ramadhan saja ( dan biasanya hanya untuk pengumpulan zakat fitrah saja), maka seyogyanya para petugas ini tidak mendapatkan bagian zakat satu perdelapan, melainkan hanyalah sekadarnya saja untuk keperluan administrasi ataupun konsumsi yang mereka butuhkan, misalnya lima persen saja. Bagian untuk amil inipun temasuk untuk biaya transportasi maupun biaya-biaya lain yang dibutuhkan untuk melaksanakan tugaasnya.Dalam kaitan amil zakat ini, ada hal yang penting untuk diketahui, bahwa amil zakat tidaklah bertingkat, mulai dari bawah sampai ke atas, misalnya mulai level RT samapai dengan Gubernur atau mungkin juga presiden.Amil Zakat hanyalah mereka yang secara langsung mengurus zakat, mencatat dan mengadministrasikannya, menagih zakat pada muzakki, melalui sosialisasi dan mendistribusikannya dengan tepat sasaran sesuai denga sasaran syariah Islamiyyah. ${ }^{28}$

\footnotetext{
${ }^{25}$ Departemen Agam RI, Alqur'an, h. 47.

${ }^{26}$ Shihab, Tafsir, h. 152

${ }^{27} \mathrm{Al}-\mathrm{Q}$ ardawi, Hukum, h. 28

${ }^{28}$ Ibid.,
} 
(Ketiga): Kelompok Muallaf, yaitu kelompok yang dianggap masih lemah imannya, karena baru masuk Islam. Mereka diberi agar bertambah kesungguhannya dalam ber-Islam dan bertambah keyakinan mereka, bahwa segala pengorbanan mereka dengan sebab masuk Islam tidaklah sia-sia. Bahwa Islam dan umatnya sangat memperhatikan mereka, bahkan memasukkannya ke dalam bagian penting dari salah satu Rukun Islam yaitu Rukun Islam Ketiga. ${ }^{29}$

(Keempat): Dalam memerdekakan budak belian. Artinya bahwa zakat itu antara lain harus dipergunakan untuk membebaskan budak belian dan menghilangkan segala bentuk perbudakan.

(Kelima): kelompok gharimin, atau kelompok orang yang berutang, yang sama sekali tidak melunasinya. Para ulama membagi kelompok ini pada dua bagian, yaitu kelompok orang yang mempunyai utang untuk kebaikan dan kemaslahatan diri dan keluarganya.Misalnya untuk membiayai dirinya dan keluarganya yang sakit, atau untuk membiayai pendidikan. ${ }^{30}$

(Keenam): Ibnu sabil, yaitu orang yang terputus bekalnya dalam perjalanan. Untuk saat sekarang, di samping para musafir yang mengadakan perjalanan yang dianjurkan agama, seperti silaturahmi, melakukan study tour pada obyek-obyek bersejarah dan bermanfaat, mungkin juga dapat dipergunakan untuk pemberian beasiswa atau beasantri (pondok pesantren) bagi mereka yang terputus pendidikannya karena ketiadaan dana.

Mungkin juga dapat dipergunakan untuk membiayai pendidikan anak-anak jalanan yang kini semakin banyak jumlahnya, atau mungkin juga dapat dipergunakan untuk merehabilitas anak-anak miskin yang terkena narkoba atau perbuatanperbuatan buruk lainnya. ${ }^{31}$

Salah satu tugas utama dari Badan Amil Zakat atau Lembaga Amil Zakat dalam mendistribusikan zakat, adalah menyusun sekala prioritas berdasarkan progamprogam yang disusun berdasarkan data-data yang akurat.Karena Badan Amil Zakat dan Lembaga Amil Zakat kini jumlahnya semakin banyak, maka tampaknya perlu semacam spesialisasi dari masing-masing lembaga. ${ }^{32}$

Misalnya Lembaga Zakat A mengkhususkan program-programnya untuk usaha yan produktif. Lembaga Zakat B pada pemberian beasiswa-beasiwa dan pelatihanpelatihan. Lembaga Zakat C pada pembangunan sarana dan prasarana, dan lain sebagainya. Sinergi dan kerja sama yang saling memperkuat, tampaknya semakin di butuhkan saat ini, karena terbatasnya dana zakat, infak, dan sedekah saat ini terkumpul, sementara jumlah penerimaan zakat (mustahik) semakin banyak. 


\section{Model pendistribusian zakat}

Sejak diundangkan UU No 38 / 1999 yang kini telah diganti No 2 Tahun 2011 tentang pengelolaan zakat memang telah banyak berdiri BAZ atau LAS baik tingkat nasional maupun lokal, bahkan sudah ada lebih dari 500 macam lembaga yang menangani masalah zakat. Zakat diwujudkan sebagai lembaga jaminan sosial untuk kesejahteraan umat dan pengentasan kemiskinan akan bisa meningkatkan lebih dari 30 triliun per tahun.

Istilah jaminan sosial adalah istilah yang berkembang didunia maju. Hampir semua negara maju menyerukan adanya program jaminan sosial. Dimaksudkan jaminan sosial, memang pengertiannya tidak seragam bagi setiap negara. ${ }^{33}$ Paling tidak arti jaminan sosial mencakup memberikan kesejahteraan keuangan pada orang-orang yang kesukaran ekonomi, meliputi asuransi pengangguran dan si sakit, kompensasi bagi pekerja pekerja yang mengalami kecelakaan, bantuan melahirkan tunjangan keluarga untuk anak-anak, dana pensiun untuk orang tua, pengobatan, pendidikan cuma-cuma, subsidi bahan pangan dan perumahan, serta bantuan karena musibah dan bencana. ${ }^{34}$

Pasal 25 UU No. 23 tahun 2011 menyebutkan bahwa zakat wajib didistribusikan kepada mustahik sesuai dengan syari'at Islam. Sedangkan cara pendistribusiannya disebutkan dalam pasal 26 UU NO. 23 tahun 2011, yaitu pendistribusian zakat dilakukan berdasarkan skala prioritas, dengan memeperhatikan prinsip pemerataan, keadilan, dan kewilayahan. ${ }^{35}$ Zakat didistribusikan lewat dua model pendistribusian secara langsung atau zakat konsumtif, dan pendistribusian secara tidak langsung, yaitu zakat produktif.

\section{Pendistribusian zakat produktif}

Zakat produktif adalah zakat yang disalurkan untuk tujuan pemberdayaan musthik, untuk memproduktifkan mustahik, atau dana zakat diinvestasikan pada bidang-bidang yang dimiliki nilai ekonomis. UU No. 23 Tahun 2011 mengamanatkan pengelolaan zakat produktif, yang dilakukan setelah kebutuhan pokok mustahik dalam bentuk zakat komsuntif telah terpenuhi. Zakat produktif memiliki nilai lebih dibandingkan zakat konsumtif, karena mengandung makna pemberdayaan mustahik. Dengan hasil zakat produktif dapat memenuhi kebutuhan zakat konsumtif. ${ }^{36}$

Zakat harus dikelola secara produktif. Penyaluran zakat secara konsumtif, hanya dubenarkan kepada fakir miskin yang tak berdaya. Sedangkan bagi fakir miskin yang berdaya, memiliki kekuatan, bahkan memiliki ilmu pengetahuan dan keterampilan, penyaluran zakat harus bersifat produktif, sehingga penyaluran zakat dapat mengentaskan mesyarakat dari kemiskinan.

\footnotetext{
${ }^{33}$ Ibid,

${ }^{34}$ UU No. 23 tahun 2011.

35UU No. 23 tahun 2011.

36UU No. 23 tahun 2011.
} 
Ada beberapa contoh zakat produktif yang dapat dilakukan lembaga zakat dalam menyalurkan dana zakatnya, diantaranya:

a. Pemberian bantuan modal kerja atau untuk meningkatkan kapasitas dan kualitas produksi.

b. Bantuan pendirian tempat usaha

c. Dukungan kepada mitra binaan untuk berperan serta dalam berbagai event dan pameran guna memasarkan hasil kerajinan dan usahanya

d. Pembentukan lembaga keuangan mikro syariah seperti BMT atau Lembaga Ekonomi Bagi Hasil (LEB)

e. Pembangunan industry, yang melibatkan mustahik-mustahik sebagai pekerjanya. $^{37}$

Dalam memproduktifkan atau menginvestasikan dana zakat, ada beberapa hal yang perlu diperhatikan, yaitu:

a. Investasi dilakukan pada bidang usaha yang halal dan dikelola oleh manajemen yang professional

b. Para amil betul-betul mengawasi jalannya investasi tersebut dengan penuh tanggung jawab dan amanah

c. Dana yang diinvestasikan adalah dan asetelah dikurangi dengan kebutuhan zakat konsumtif

d. Ada laporan berkala kepada public, khususnya kepada muzzaki, sehingga pengelolaan dana tersebut dapat dilakukan secara transparan

e. Bentuk investasi yang dilakukan disetujui oleh badan Pembina atau semaca, dewan syariah yang terdiri dari pakar dan ulama, tidak diputuskan sendiri oleh badan amil zakat yang bersangkutan. ${ }^{38}$

Pola distribusi produktif yang mengedepankan skema qardul hasan dapat diilustrasikan sebagai berikut:

a. Muzaki membayar zakat kepada BAZ/LAZ

b. BAZ/LAZ menyalurkan kepada mustahik I untuk dimanfaatkan sebagai modal usaha

c. Usaha untung maka mustahik mengembalikan modalnya keada BAZ/LAZ

d. Usaha rugi maka mustahik tidak perlu mengembalikan modalnya

e. BAZ/LAZ menerima modal kembali dari mustahik yang mengalami keuntungan dalam usaha

f. BAZ/LAZ memilih menyalurkan kembali kepada mustahik untuk penambahan modal

g. BAZ/LAZ memilih menyalurkan kepada mustahik II untuk dimanfaatkan sebagai modal usaha... dan begitu seterusnya. ${ }^{39}$

Selain skema qardul hasan, ada fenomena yang menarik untuk dikaji, yaitu penyaluran dana zakat produktif yang memanfaatkan skema mudhorobah. Skema ini menjadi sangat menarik, karena dalam bahasa ilmu fikih, inovasi ini tentunya akan

111.

${ }^{37}$ Saifudin Zuhri, Zakat di Era Reformasi (Semarang: IAIN Walisongo, Semarang, 2012), h.

${ }^{38}$ Ibid.,

${ }^{39}$ Didin hafidhuddin, Zakat Dalam Perekonomian Modern (Jakarta: Gema Insani Press, 2002), h. 132-139. 
mengundang prodan kontra, bila mengingat pada pola investasi dana zakat, titik tolak perdebatan kajian fikih, pada umumnya bertumpu kepada sejumlah permasalahan. ${ }^{40}$ Berikut adalah penulisan skema penyaluran produktif dana zakat dengan skim mudhorobab: Keterangan:

a. Muzaki membayar zakat kepada BAZ/LAZ

b. BAZ/LAZ menyalurkan kepada mustahik I untuk dimanfaatkan sebagai modal hasil keuntungan

c. Usaha untung, maka mustahik dan BAZ / LAZ saling membagi hasil keuntungan

d. Mustahik mengambil sejumlah persen keuntungan dan sejumlah persen dikembalikan kepada BAZ/LAZ berikut keuntungan usaha

e. BAZ/LAZ menerima modal kembali berikut persentase keuntungan usaha

f. BAZ/LAZ memilih menyalurkan kembali kepada mustahik untuk penmabahan modal

g. BAZ/LAZ memilih menyalurkan kepada mustahik II untuk dimanfaatkan sebagai modal uasaha... dan begitu seterusnya

h. Usaha rugi maka mustahik tidak perlu mengembalikan modalnya. ${ }^{41}$

Apapun skema yang dikembangkan oleh sebuah lembaga amil zakat tidak berpengaruh karena sebenarnya tolok ukur paling utama adalah bagaimana bisa mendekatkan strata kesejahteraan masyarakat defisit kepada strata kesejahteraan masyarakat surplus. Untuk itu BAZ/LAZ tidak perlu khawatir dalam pembuatan dan mempolakan sebuah inovasi pendistribusian produktif selama masih dalam frame pemberdayaan dan azakat yang terkumpul. Dalam UU No. 28 Tahun 1999 tentang pengelolaan zakat, pasal 29 menyebutkan bahwa prosedur pendayagunaan hasil pengumpulan zakat untuk usaha produktif ditetapkan sebagai berikut:

a. Melakukan study kelayakan

b. Menetapkan jenis usaha produktif

c. Melakukan bimbingan dan penyuluhan

d Melakukan pemantauan, pengendalian, dan pengawasan

e.Mengadakan evaluasi

f. Membuat laporan. ${ }^{42}$

\section{Pendistribusian zakat konsumtif}

Biro Pusat Statistik (BPS) mengukur kemiskinan dari ketidakmampuan orang keluarga dalam mengonsumsi kebutuhan dasar (tingkat konsumsi), konsepnya menjadikan konsumsi beras sebagai indicator utama, sedangkan Badan Koordinasi Keluarga Berencana Nasional (BKKBN) melihatnya dari ketidakmampuan memenuhi kebutuhan dasar dan kebutuhan sosial psikologis (tingkat kesejahteraan),

${ }^{40}$ Arif Mufraini, Akuntansi dan Manajemen Zakat: Mengomunikasikan Kesadaran dan Membangun Jaringan (Jakarta: Kencana Prenade Media Group, 2006), h. 160-162.

${ }^{41}$ Ahmad Furqon, Manajemen Zakat (Semarang: Karya Abadi Jaya, 2015), h. 85-89.

42UU No. 28 Tahun 1999 tentang pengelolaan zakat, pasal 29. 
kemudian Uinited Nation Develpoment Program Perserikatan Bangsa-Bangsa (UNDPPBB) mengukur berdasarkan.

Ketidakmampuan orang dalam memperluas pilihan-pilihan hidupnya pada tataran transisi ekonomi dan demokrasi Indonesia (model pembangunan manusia). ${ }^{43}$ Ke semua model pengukuran diatas, jika dikaitkan dengan pengembangan pola distribusi dana zakat secara konsumtif berarti konsep dari pola pendistribusian diarahkan kepada:

a. Upaya pemenuhan kebutuhan konsumsi dasar dari para mustahik

b. Upaya pemenuhan kebutuhan yang berkaitan dengan tingkat kesejahteraan sosial dan psikologi

c. Upaya pemenuhan kebutuhan yang berkaitan dengan peningkatan sumber daya manusia agar dapat bersaing hidup di alam transisi ekonomi dan demokrasi Indonesia. ${ }^{44}$

Diantara model pendistribusian zakat konsumtif adalah:

a. Bantuan pangan, pakaian, dan tempat tinggal

b. Bantuan pendidikan: Mendirikan dan atau membantu pembangunan / renovasi madrasah dan pondok pesantren. Pembangunan sarana dan prasarana keterampilan, Membangun perpustakaan dan Beasiswa

c. Sarana kesehatan: Membangun klinik / rumah sakit gratis bagi fakir miskin dan Membangun rumah bersalin gratis bagi fakir miskin

d. Sarana sosial: Membangun panti asuhan bagi yatim piatu dan lansia, Membangun rumah singgah bagi gelandangan dan Membangun rumah bagi penderita disabilitas. ${ }^{45}$

Sebelum mendistribusikan zakat konsumtif perlu dilakukan perancaan dengan melakukan observasi lapangan untuk menentukan kelompok masyarakat yang akan mendapatkan bantuan. Penentuan mustahik dan pelaksaan pendistribusian zakat dapat dilakukan dengan bekerjasama dengan pihak terkait seperti pemerintah setempat, LSM, ataupun ormas.

Tujuan zakat adalah untuk pengentaskan kemiskinan, sedangkan asas pemerataan adalah zakat tersebut dibagi rata keseluruhan ashnaf, kecuali apabila zakatnya sedikit maka fakir dan miskin adalah prioritas utama sebagia penerima dana zakat tersebut. Zakat didistribusikan lewat dua model pendistribusian, yaitu pendistribusian secara langsung atau zakat konsumtif, dan pendistribusian secara tidak langsung, yaitu zakat produktif. Dalam pendistrbusian zakat konsumtif perlu adanya perencanaan dalam melakukan observasi lapangan untuk menentukan kelompok masyarakat yang akan mendapatkan bantuan. Sedangkan pendistribusian zakat produktif adalah zakat yang disalurkan untuk tujuan pemberdayaan mustahik,

\footnotetext{
${ }^{43}$ Andri Wibisono, organisasi-dan manajemen zakat, http://www./lifazih/_,Diakses, 24 Mei 2020.

${ }^{44}$ Mufraini, Akuntansi, h. 148-152

${ }^{45}$ Saifudin Zuhri, Zakat di Era Reformasi (Semarang: Fakultas Tarbiyah IAIN Walisongo,
} 2012), h. 111-112. 
untuk memproduktifkan mustahik, atau dana zakat diinvestasikan pada bidangbidang yang memiliki nilai ekonomis.

\section{Kesimpulan}

Dalam proses pengelolaan zakat dapat direlisasikan dengan sungguhsungguh, tentu saja ini perlu didukung dengan menejemen yang baik, seperti pernah dilakukan pada masa awal-awal Islam. Pengelolaan zakat secara efektif dan efisien, perlu di-manage dengan baik. Karena itu, dalam pengelolaan zakat memberikan penerapan fungsi menejemen modern. Dalam hal ini, mengambil model menejemen sederhana yang dipelopori oleh James Stoner. Model menejemen tersebut meliputi Perencanaan, pengorganisasian, pengarahan, dan pengontrolan. Keempat aktivitas itu, perlu diterapkan dalam setiap tahapan aktivitas pengelolaan zakat.

Pasal 25 UU No. 23 tahun 2011 menyebutkan bahwa zakat wajib didistribusikan kepada mustahik sesuai dengan syari'at Islam. Sedangkan cara pendistribusiannya disebutkan dalam pasal 26 UU NO. 23 tahun 2011, yaitu pendistribusian zakat dilakukan berdasarkan skala prioritas, dengan memeperhatikan prinsip pemerataan, keadilan, dan kewilayahan. Zakat didistribusikan lewat dua model pendistribusian secara langsung atau zakat konsumtif, dan pendistribusian secara tidak langsung, yaitu zakat produktif.

\section{Daftar Pustaka}

Al-Qardhawi, Yusuf. Fiqih Zakat. Jakarta: Ar-Risalah, 1991

Alwi Hasan, dkk. Kamus Besar Bahasa Indonesia. Jakarta: Balai Pustaka, 2008

Asnaini. Zakat Produktif dalam Perspektif Islam. Yogyakarta: Pustaka Pelajar, 2008

Cikka, Hairuddin. Strategi Komunikasi Guru Memotivasi Peserta Didik Dalam Meningkatkan Prestasi Belajar, Al-mishbah, Vol.15 No. 2 Juli - Desember 2019, 373.

Djazuli, Yadi Janwari. Lembaga-lembaga Perekonomian Umat. Jakarta: Raja Grafindo Persada, 2002

Furqon, Ahmad. Manajemen Zakat. Semarang: Karya Abadi Jaya, 2015

G.R. Terry dan Leslie. Dasar-Dasar Manajemen, Penerjemah: G.A. Ticoalu. Jakarta: PT Bumi Aksara, 2013

Hafidhuddin, Didin. Zakat Dalam Perekonomian Modern. Jakarta: Gema Insani Press, 2002 
Moderasi Jurnal Studi Ilmu Pengetahuan Sosial, Volume I, No. 2, h. 34-50

Hafifdhuddin, Didin. Zakat dalam Perekonomian Modern. Jakarta: Gema Insani Press 2002

Hasan, Muhammad. Manajemen Zakat. Yogyakarta: Idea Press, 2011

HS, Fahruddin. Ensiklopedi Alqur'an. Jakarta: Rineka Cipta, 1992

Khasanah, Umrotun. Manajemen Zakat Modern. Malang: UIN-Maliki Press, 2010

Mubyarto. Membangun Sistem Ekonomi. Yogyakarta: BPFE, 2000

Mufraini, Arif. Akuntansi dan Manajemen Zakat: Mengomunikasikan Kesadaran dan Membangun Jaringan. Jakarta: Kencana Prenade Media Group, 2006

Noor, Ruslan Abdul Ghofur. Konsep Distribusi Ekonomi Islam dan Format Keadilan Ekonomi di Indonesia. Yogyakarta: Pustaka Pelajar, 2013

Raharjo, M. Darmawan. Islam dan Transformasi Sosial Ekonomi. Jakarta: LSI, 1999

Rofik, Ahmad. Fiqh Kontekstual. Semarang: Offset, 2004

Sabiq, Sayyid. Fiqib Sunnab: Kitab Azzakah Terjemah: Beni Sarbeni "Panduan Zakat ". Bogor: Pustaka Ibnu Katsir, 2005

Sanusi, Anwar. Metodologi Penelitian Bisnis. Jakarta: Salemba Empat, 2016

Sari, Elsi Kartika. Pengantar Hukum Zakat dan Wakaf.Jakarta: Grasindo, 2006

Setiawan, Herri. Membership Fundraising: Panduan Praktis Menggalang Dana Lewat Skema Keanggotaan Bagi Organisasi Nirlaba. Depok: Piramedia, 2006

Sudirman. Zakat dalam Pusaran Arus Modernitas. Malang: UIN Malang Pres, 2007

Sudjana. Manajemen Program Pendidikan. Bandung: Falah Production, 2004

Undang-Undang Republik Indonesia Nomor 38 Tahun 1999 Tentang Pengelolaan Zakat pasal 1.

Wibisono, Andri. organisasi-dan manajemen rakat, http://www./lifazih/ ,Diakses, 24 Mei 2020

Winardi. Kepemimpinan dalam Manajemen. Jakarta: PT Rineka Cipta, 2000

Zuhri, Saefudin. Zakat di Era Reformasi. Semarang: Aneka Ilmu, 2004 